\title{
Soybean yield in response to application of phosphate rock associated with triple superphosphate
}

\author{
Adilson de Oliveira Júnior ${ }^{1 *}$; Luís Ignácio Prochnow²; Dirceu Klepker ${ }^{3}$ \\ ${ }^{1}$ Embrapa Soja, Rod. Carlos João Strass, Distrito de Warta, C.P. 231 - 86001-970 - Londrina, PR - Brasil. \\ ${ }^{2}$ International Plant Nutrition Institute/IPNI, R. Alfredo Guedes, 1949 - C.P. 400 - 13400-970 - Piracicaba, \\ SP - Brasil. \\ ${ }^{3}$ Embrapa Soja - Setor Experimental de Balsas, R. Cohab, 813 - C.P. 131 - 65800-000 - Balsas, MA - Brasil. \\ *Corresponding author < adilson@cnpso.embrapa.br>
}

\begin{abstract}
Soybean (Glycine max L. Merrill) crop started to be planted in the Brazilian Cerrado in the 1970's, and this region currently contributes with $57 \%$ of total soybean production in Brazil. Under natural conditions in this region, the soils present chemical limitations such as low $\mathrm{pH}$, low Cation Exchange Capacity, low nutrient availability, and moreover, clayey soils have a high $\mathrm{P}$ fixation capacity mainly due to high contents of $\mathrm{Fe} / \mathrm{Al}$ oxides. Since $\mathrm{P}$ is the most limiting nutrient is this region, a study was performed in the state of Maranhão, Brazil, in a Typic Hapludox, with clayey texture and low available P (extracted by resin). Treatments were defined to evaluate soybean response to broadcast Arad phosphate rock (PR) plus banded triple superphosphate (TSP) and to evaluate the soybean response to three proportions of PR and TSP. The experiment was established in October 2004 and was carried out for three consecutive crop years (2004/05 to 2006/07). The associated use of PR and TSP, in several situations, resulted in yields at least similar to that obtained with the use of the water soluble P source and, in some cases, even using lower P rates. Regarding the "mixtures", a linear response was observed when they were banded; however, when they were broadcasted, no increase in yield was observed above $50 \%$ of relative solubility. In conclusion, the association of sources differing in solubility may be a feasible agronomic option for P fertilizer management of soybeans.

Key words: Brazil, Glycine max L. Merrill, Oxisols, P source solubility, phosphorus, cerrado soils
\end{abstract}

\section{Produtividade da soja em resposta à aplicação de fosfato de rocha associado ao superfosfato triplo}

\begin{abstract}
RESUMO: O cultivo de soja (Glycine max L. Merrill) na região do Cerrado iniciou-se na década de 1970 e, atualmente, representa aproximadamente $57 \%$ da produção total do Brasil. Sob condições naturais, os solos dessa região apresentam limitações químicas, como baixos valores de $\mathrm{pH}$, de Capacidade de Troca de Cátions, de disponibilidade de nutrientes, bem como elevada capacidade de fixação de $\mathrm{P}$ nos solos de textura argilosa, principalmente pelos altos teores de óxidos de Fe/Al. Levando-se em conta que o $\mathrm{P}$ é o nutriente mais limitante à produção nessa região, foi instalado um experimento no estado do Maranhão, em Latossolo Vermelho-Amarelo distrófico argiloso e com baixo teor disponível de $\mathrm{P}$ (extraído com resina). Objetivou-se verificar a resposta da cultura à aplicação do fosfato de rocha Arad (FR) em área total mais superfosfato triplo (SFT) em aplicação localizada; e verificar a resposta da cultura a três proporções de FR e SFT. O experimento foi instalado em outubro de 2004 e conduzido por três safras consecutivas (2004/05 a 2006/07). A utilização associada de FR e SFT, em várias condições, resultou em produtividades no mínimo semelhantes à obtida com a fonte solúvel e, em alguns casos, até utilizando menores quantidades de P. Quanto às "misturas", verificou-se resposta linear para a aplicação localizada; entretanto, para a aplicação a lanço, não houve aumento na produtividade a partir de $50 \%$ de solubilidade relativa. Logo, a associação de fontes com solubilidades distintas pode ser uma opção agronomicamente viável para o manejo da adubação fosfatada da soja.

Palavras-chave: Brasil, Glycine max L. Merrill, Latossolos, solubilidade de fontes de P, fósforo, solos sob Cerrado
\end{abstract}

\section{Introduction}

Brazil started to be considered an important country in the agricultural scenario after the introduction of soybean (Glycine $\max$ L. Merrill) crop. Nowadays, this is the largest food crop in the country, worth nearly US\$ 17 billion in 2008 . In the 1960's, the crop was limited to the Southern Region of Brazil, but since then breeders have developed varieties that can grow in most parts of the country. Agricultural scientists have tamed the highly acidic soils of the Brazilian Cerrado through applications of lime and other soil amend- ments. They also have reduced fertilizer costs by developing methods to inoculate Leguminosae seeds with rhizobia, a type of bacteria that colonize the roots of certain plants, such as soybeans, and promote nitrogen fixation (Tollefson, 2010).

Although soils with low chemical fertility are predominant in these areas, the climate conditions and slope are adequate for cropping. The whole region is known as the Cerrado and covers approximately $25 \%$ of Brazil's total area. Most of the soils under Cerrado are Oxisols, but there are also significant zones of Quartzipsamments and Ultisols. 
These soils have low pH, low Cation Exchange Capacity (CEC), low nutrient content, high P fixation capacity (clayey soils), and high exchangeable Al saturation (Leal and Velloso, 1973). Phosphorus is the main limiting nutrient to crop production in this region. Lopes and Cox (1977) carried out a soil characterization survey in the Cerrado and observed that $92 \%$ of the samples collected presented available P levels (extracted by Mehlich 1) lower than $2 \mathrm{mg} \mathrm{dm}^{-3}$. Nevertheless, the continuous correct management of soil fertility and the adoption of practices that promote better fertilizer efficiency, such as no-tillage, have been leading to increased $\mathrm{P}$ availability in these areas.

Several mineral and organic $\mathrm{P}$ sources are available for agricultural purposes. Worldwide, fully acidulated phosphates (superphosphates and ammoniated phosphates) constitute the main sources of $\mathrm{P}$ used for agricultural production (Prochnow et al., 2004a). As an alternative to the use of superphosphates, phosphate rocks or an association of both sources can be used to manage $\mathrm{P}$ fertilization with sources presenting distinct solubility traits (Chien et al., 2009). The joint utilization of these sources can be either accomplished by applying combinations of phosphate rock and soluble sources (Chien et al., 1987; Franzini et al., 2009a, 2009b;
Nachtigall et al., 1989; Menon et al., 1991; Prochnow et al., 2004b; Villanueva et al., 2006) or by applying them separately but in the same area (associated use).

This study aimed at evaluating soybean yield as a response to the application of $\mathrm{P}$ sources in an Oxisol in the Brazilian Cerrado. It was hypothesized that the use of natural rock phosphates might be possible to replace other soluble sources of $\mathrm{P}$ traditionally used in soybeans, as well as associations of $\mathrm{P}$ fertilizers with intermediate solubility in water.

\section{Material and Methods}

The experiment was established in October 2004 in the southern part of the state of Maranhão (6 $46^{\circ} 08^{\prime \prime} \mathrm{S}$, $\left.45^{\circ} 45^{\prime} 50^{\prime \prime} \mathrm{W}\right)$, in a Typic Hapludox, with a clayey texture (510 $\mathrm{g} \mathrm{kg}^{-1}$ ), available $\mathrm{P}$ (resin) level of $2 \mathrm{mg} \mathrm{dm}^{-3}$, and maximum P fixation capacity (Langmuir isotherm) of $0.776 \mathrm{mg}$ $\mathrm{g}^{-1}$. The area was primarily established in 2000/01 and limed in October 2001 with $8 \mathrm{t} \mathrm{ha}^{-1}$ of limestone (Relative Neutralizing Value $=70 \%$ ). This liming rate was calculated to raise the soil $\mathrm{pH}$ in water to approximately 5.5 and the base saturation to $60 \%$. After liming, the area was left fallow until the beginning of the experiment.

Table 1 - Description of treatments.

\begin{tabular}{|c|c|c|c|c|c|}
\hline \multirow{2}{*}{ P source ${ }^{A}$} & \multirow{2}{*}{ Application method } & \multicolumn{4}{|c|}{ P rate ${ }^{\mathrm{B}}$} \\
\hline & & $2004 / 05$ & $2005 / 06$ & $2006 / 07$ & Total \\
\hline & & \multicolumn{4}{|c|}{ - } \\
\hline - & - & 0 & 0 & 0 & 0 \\
\hline TSP & Broadcast & 100 & 100 & $0 ; 100^{\mathrm{C}}$ & $200 ; 300$ \\
\hline TSP & Broadcast & 200 & 200 & $0 ; 200^{\mathrm{C}}$ & $400 ; 600$ \\
\hline PR & Broadcast & 100 & 100 & 0 & 200 \\
\hline PR & Broadcast & 200 & 200 & 0 & 400 \\
\hline PR & Broadcast & 400 & 400 & 0 & 800 \\
\hline TSP & Banded & 100 & 100 & 0 & 300 \\
\hline TSP & Banded & 200 & 200 & 0 & 400 \\
\hline $\mathrm{PR}+\mathrm{TSP}$ & Broadcast + Banded & $100+100$ & $0+100$ & 0 & 300 \\
\hline $\mathrm{PR}+\mathrm{TSP}$ & Broadcast + Banded & $100+200$ & $0+200$ & 0 & 500 \\
\hline $\mathrm{PR}+\mathrm{TSP}$ & Broadcast + Banded & $200+100$ & $0+100$ & 0 & 400 \\
\hline $\mathrm{PR}+\mathrm{TSP}$ & Broadcast + Banded & $200+200$ & $0+200$ & 0 & 600 \\
\hline $\mathrm{PR}+\mathrm{TSP}$ & Broadcast + Banded & $400+100$ & $0+100$ & 0 & 600 \\
\hline $\mathrm{PR}+\mathrm{TSP}$ & Broadcast + Banded & $400+200$ & $0+200$ & 0 & 800 \\
\hline PR:TSP & Broadcast & $50+150$ & $50+150$ & 0 & 400 \\
\hline PR:TSP & Broadcast & $100+100$ & $100+100$ & 0 & 400 \\
\hline PR:TSP & Broadcast & $150+50$ & $150+50$ & 0 & 400 \\
\hline PR:TSP & Banded & $50+150$ & $50+150$ & 0 & 400 \\
\hline PR:TSP & Banded & $100+100$ & $100+100$ & 0 & 400 \\
\hline PR:TSP & Banded & $150+50$ & $150+50$ & 0 & 400 \\
\hline
\end{tabular}

ATP: Triple superphosphate; PR: Arad phosphate rock; PR+TSP: Broadcast PR + banded TSP; PR:TSP: "mixtures" of P sources in three proportions (3:1, 1:1, and 1:3); ${ }^{\mathrm{B}}$ The rate of TSP applied was calculated based on the NAC+ $\mathrm{H}_{2} \mathrm{O}$ soluble $\mathrm{P}$ and the rate of PR was determined from the total $\mathrm{P}$ content; ${ }^{\mathrm{C}}$ Treatments corresponding to $\mathrm{P}$ response curve rates that were applied as broadcast TSP subdividing the respective plots. 
The treatments were defined aiming at assessing the crop response to broadcasted Arad phosphate rock (PR) in association with banded triple superphosphate (TSP), a soluble source of $\mathrm{P}$, as well as the crop response to the application of a specific rate of $\mathrm{P}$, either broadcast or banded in the seed row, supplied by three proportions of PR and TSP, from now on called "mixtures" (Table 1). Although the combination of three proportions of PR and TSP cannot be considered an actual mixture, since PR was applied in the ungrounded form and TSP was applied as granules, this term is used between quotation marks throughout the text referring to the application of a fixed rate of $\mathrm{P}$ supplied by these three proportions of the two sources.

The experiment followed a randomized block design with three replications. Each plot covered an area of $72 \mathrm{~m}^{2}$ $(6 \mathrm{~m} \times 12 \mathrm{~m})$ with 15 rows of soybeans planted at $0.40 \mathrm{~m}$ row spacing. The useful area of each plot was $12 \mathrm{~m}^{2}(2.4 \mathrm{~m}$ $\times 5 \mathrm{~m})$.

The experiment was carried out on three consecutive crop years (2004/05 to 2006/07), cultivating soybeans under a conventional system, using BRS Sambaíba variety. The treatments were applied to the first two crops, and the residual effect of the previous applications was evaluated in the $3^{\text {rd }}$ one. Given that it was necessary to apply the nutrient within the study year in order to calculate its residual effect (Pimentel-Gomes and Conagin, 1991), P response curve rates were applied again as broadcast TSP subdividing the corresponding plots. The rate of TSP was calculated based on the extraction of neutral ammonium citrate + water $\left(\mathrm{NAC}+\mathrm{H}_{2} \mathrm{O}\right)$ soluble $\mathrm{P}\left(41.5 \% \mathrm{P}_{2} \mathrm{O}_{5}\right)$, while the rate of $\mathrm{PR}$ was determined from the total $\mathrm{P}$ content $(33.3 \%$ $\left.\mathrm{P}_{2} \mathrm{O}_{5}\right)$.

Rates of potassium, sulfur, and micronutrients used, as well as the seeding dates of each crop are in Table 2. Sulfur and micronutrients were applied only in the first crop year, at rates considered sufficient to maintain adequate availability for the following crops (Embrapa, 2003). The rainfall during the three crop years was adequate for soybean development. The accumulated rainfall between December and June ranged from $800 \mathrm{~mm}$ to $1,500 \mathrm{~mm}$, depending on the crop year. Despite the variation in this value, the distribution within each month was uniform, with no occurrence of dry periods, which could cause damage to plant growth. Grain yield was the main variable evaluated through harvesting six 5 -meter long rows of soybeans, whereas in the divided plots, three 5-meter long rows were harvested.
All data generated during the first crop year (2004/05) from the broadcast PR treatments in association with banded TSP was evaluated by multiple regression, considering $P$ rates supplied as broadcast PR and banded TSP as independent variables. In addition, through horizontal comparison studies, it was possible to determine the combinations of $\mathrm{P}$ rates that resulted in a certain yield level (isolines). The SigmaPlot ${ }^{\mathbb{R}}$ version 10 (Systat Software, 2006) and TableCurve 3D ${ }^{\circledR}$ version 4.0 (Systat Software, 2002) software products were used.

In the $2^{\text {nd }}$ crop year $(2005 / 06)$, the model was adjusted as in the previous crop, although no broadcast PR application was performed (Table 1). Nonetheless, the interpretation of the multiple regression equation must take into account that one independent variable represents PR application in 2004/05, and the other represents the annual application of P (2004/05 and 2005/06) as banded TSP.

In the $3^{\text {rd }}$ crop year $(2006 / 07)$, under the residual effect of both sources, the model was adjusted again as a function of $\mathrm{P}$ rates. In this case, one independent variable represents the PR application carried out in 2004/05, and the other represents TSP application performed in 2004/05 and 2005/ 06.

The three models were adjusted using soybean grain yield as the response variable. In the vertical comparison, isolines corresponding to the maximum technical efficiency values (Y $\max )$ were indicated for the three crop years, and the values corresponding to $90 \%$ of the $\hat{Y} \max (0.9 \hat{Y} \max )$ were indicated for the two first ones.

The treatment arrangement enabled calculation of PR contribution in the final yield results in order to obtain the immediate effect of phosphate rock $\left(\mathrm{IE}_{\mathrm{PR}}\right)$ with or without a soluble source in the first crop year $(2004 / 05)$, as well as $\mathrm{PR}$ residual effect $\left(\mathrm{RE}_{\mathrm{PR}}\right)$ with a soluble source in the $2^{\text {nd }}$ crop year $(2005 / 06)$ and without it in the $3^{\text {rd }}$ crop year $(2006 / 07)$. The generic models used in the calculation of the response variation $(\mathrm{Y})$ due to $\mathrm{PR}\left(\Delta \mathrm{Y}_{\mathrm{PR}}\right)$ are described in equations 1 to 3 .

$$
\begin{aligned}
& \text { 2004/05: } \Delta Y_{P R_{i}}=\left(Y_{P R_{i}^{n^{1}}+T S P_{j}^{n^{1}}}-Y_{T S P_{j}^{n^{1}}}\right) \\
& \text { 2005/06: } \Delta Y_{P R_{i}}=\left(Y_{P R_{i}^{n^{1}}+T S P_{j}^{n^{1-2}}}-Y_{T S P_{j}^{n^{1-2}}}\right) \\
& \text { 2006/07: } \Delta Y_{P R_{i}}=\left(Y_{P R_{i}^{n^{1}}+T S P_{j}^{n^{1-2}}}-Y_{T S P_{j}^{n^{1-3}}}\right)-\left(Y_{T S P_{j}^{n^{1-2}}}-Y_{T S P_{j}^{n^{1-3}}}\right)
\end{aligned}
$$

Table 2 - Seeding dates and potassium, sulfur, and micronutrient rates applied in each crop year.

\begin{tabular}{lcccccccccc}
\hline \multirow{2}{*}{ Crop year } & \multirow{2}{*}{ Seeding date } & \multicolumn{9}{c}{ Nutrient rate $^{\mathrm{A}}$} \\
\cline { 3 - 9 } & & $\mathrm{K}_{2} \mathrm{O}$ & $\mathrm{S}$ & $\mathrm{Zn}$ & $\mathrm{Mn}$ & $\mathrm{Cu}$ & $\mathrm{B}$ & $\mathrm{Mo}$ & $\mathrm{Co}$ \\
\hline $2004 / 2005$ & $12 / 12 / 2004$ & 100 & 150 & 5 & 5 & 5 & 2.5 & 150 & 15 \\
$2005 / 2006$ & $12 / 17 / 2005$ & 80 & 0 & 0 & 0 & 0 & 0.0 & 0 & 0 \\
$2006 / 2007$ & $12 / 11 / 2006$ & 80 & 0 & 0 & 0 & 0 & 0.0 & 0 & 0 \\
\hline
\end{tabular}

${ }^{\mathrm{A}} \mathrm{K}_{2} \mathrm{O}$ : potassium chloride; S: elemental sulfur; $\mathrm{Zn}, \mathrm{Mn}$, Cu e Co: sulfate forms; B: boric acid; Mo: sodium molybdate; all the sources were broadcast. 
where: $i=P$ rate: broadcast $P R ; j=P$ rate: banded $S P ; n^{1}=P$ source applied in 2004/05; $\mathrm{n}^{1\urcorner 2}=\mathrm{P}$ source applied in 2004/ 05 and 2005/06; $\mathrm{n}^{1 \neg 3}=\mathrm{P}$ source applied in 2004/05, 2005/ 06 , and 2006/07.

The $\Delta \mathrm{Y}_{\mathrm{PR}}$ values in the $3^{\text {rd }}$ crop year $(2006 / 07)$ (Eq. 3) were calculated in two steps. In the first step, the annual broadcast TSP application (obtained from the subdivision of the corresponding plots) served as a reference, making it possible to obtain the yield variation as a function of broadcast PR and banded TSP applications $\left(\Delta \mathrm{Y}_{\mathrm{PR}+\mathrm{TSP}}\right)$. The $2^{\text {nd }}$ step was performed using banded TSP applications in the first (2004/05) and $2^{\text {nd }}(2005 / 06)$ crop years as a reference. Therefore, it was possible to isolate the contribution of PR in the $3^{\text {rd }}$ crop year (2006/07) even under the residual effect of banded TSP.

Using $\Delta \mathrm{Y}_{\mathrm{PR}}$ data, it was possible to calculate PR contribution as percentages, as follows:

$\mathrm{IE}_{\mathrm{PR}}(\%)$ or $\mathrm{RE}_{\mathrm{PR}}(\%)=\left(\frac{\Delta \mathrm{Y}_{\mathrm{PR}}}{\mathrm{Y}}\right) \times 100$

where: $\mathrm{IE}_{\mathrm{PR}}$ or $\mathrm{RE}_{\mathrm{PR}}=$ contribution of $\mathrm{PR}$ expressed as a percentage of the final $\mathrm{Y}$ value; $\Delta \mathrm{Y}_{\mathrm{PR}}=$ variation in the $\mathrm{Y}$ variable due to $P R ; Y=$ dependent or response variable value obtained in a given treatment

All data regarding the immediate and residual effects of PR in the $2^{\text {nd }}$ crop year $(2005 / 06)$ were related to their corresponding rates through multiple regression models, allowing interpolations within the applied P (both PR and TSP) interval. The isolines for the corresponding adjustments were also calculated (horizontal comparison). These multiple regression models were not adjusted for the $3^{\text {rd }}$ crop year. Additionally, the average soybean yields obtained in each of the three crop years were compared by a multiple comparison test as a function of the treatments.

The results obtained for the "mixtures" were analyzed by orthogonal contrasts, comparing groups of sources (higher vs. lower solubility) and application forms (broadcast vs. banded), as well as using simple linear regression models, in which soybean yields in each crop year were correlated with the average of the three crop years as a function of source/ "mixture" relative solubility (RS).

The fertilizer application in different proportions while maintaining the rate of $\mathrm{P}_{2} \mathrm{O}_{5}$ at $200 \mathrm{~kg} \mathrm{ha}{ }^{-1}$ resulted in five levels of RS, corresponding to the percentages of the watersoluble sources total content, which were used in the regression analyses as independent model variables.

The significance of the equation estimation parameters was evaluated for all the adjusted regression models taking into consideration the $1 \%, 5 \%, 10 \%$, and non-significant probabilities, represented by $* *, *,{ }^{\circ}$ and ${ }^{\mathrm{ns}}$, respectively.

\section{Results and Discussion}

Both independent variables had a positive influence on crop response (Figure 1). However, the single application of each source resulted in yields lower than $2,500 \mathrm{~kg} \mathrm{ha}^{-1}$, while several source combinations resulted in yields higher than $3,000 \mathrm{~kg} \mathrm{ha}{ }^{-1}$. Therefore, it is possible to reach high yields through adequate management of P sources. Since no economic analyses were performed, an isoline was drawn for the value of $2820 \mathrm{~kg} \mathrm{ha}^{-1}$, which corresponds to $90 \%$ of the maximum yield $\left(3130 \mathrm{~kg} \mathrm{ha}^{-1}\right)$. Based on these yield values, it was possible to mathematically single out the contribution of $\mathrm{PR}$ in the final yield value $\left(\mathrm{IE}_{\mathrm{PR}}\right)$ when applied separately or in association with TSP. PR contribution decreased exponentially with increased participation of the highly soluble source, regardless of the rate applied (Figure 2). Nevertheless, when the highest banded $\mathrm{P}$ rate $\left(200 \mathrm{~kg} \mathrm{ha}^{-1}\right)$ was used, PR applied at the rates of 100,200 , and $400 \mathrm{~kg} \mathrm{ha}^{-1}$ of $\mathrm{P}_{2} \mathrm{O}_{5}$ resulted yield increases of $12 \%, 22 \%$, and $17 \%$, respectively. $\mathrm{IE}_{\mathrm{PR}}$ remained stable at rates above $150-200 \mathrm{~kg} \mathrm{ha}^{-1}$ of

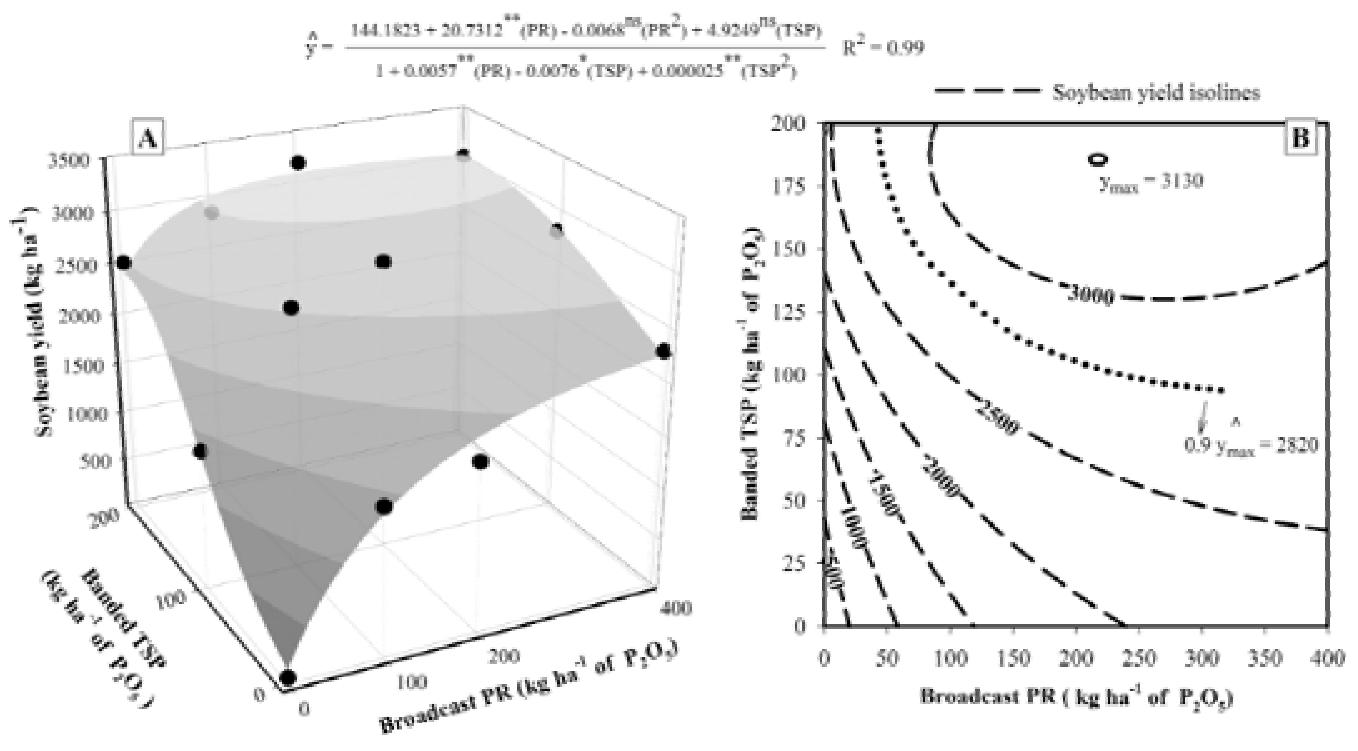

Figure 1 - Soybean yield in the first crop year (2004/05) as a function of broadcast PR and banded TSP application (A) and the corresponding isolines for the adjusted regression model (B).

Sci. Agric. (Piracicaba, Braz.), v.68, n.3, p.376-385, May/June 2011 
$\mathrm{P}_{2} \mathrm{O}_{5}$, regardless of the amount of TSP applied (Figure 2b). These results indicate that PR dissolution reactions reached maximum values at rates close to $200 \mathrm{~kg} \mathrm{ha}^{-1}$ of $\mathrm{P}_{2} \mathrm{O}_{5}$. Therefore, if immediate effects are expected, the use of $\mathrm{P}$ rates higher than this value is not a viable option.

In the $2^{\text {nd }}$ crop year $(2005 / 06)$, soybean response was evaluated as a function of banded TSP annual application and the residual effects of PR application in the previous year (Figure 3). Isolated TSP application resulted in yields ranging from 2,000 to $2,700 \mathrm{~kg} \mathrm{ha}^{-1}$. However, higher yields (> $3,000 \mathrm{~kg} \mathrm{ha}^{-1}$ ) were only reached when considering the contribution of PR applied in the previous year (Figure 3B), which highlights the positive interaction between sources.
Another probable explanation for this interaction is the initial effect caused by the water-soluble $\mathrm{P}$ that would lead to higher plant uptake of P from PR due to better root system development (Chien et al., 1987).

The maximum yield estimated by the model function was $3,203 \mathrm{~kg} \mathrm{ha}{ }^{-1}$. This value was obtained using P rates (broadcast PR) between 320 and $330 \mathrm{~kg} \mathrm{ha}^{-1}$ of $\mathrm{P}_{2} \mathrm{O}_{5}$ and annual application of 158 to $165 \mathrm{~kg} \mathrm{ha}^{-1}$ of $\mathrm{P}_{2} \mathrm{O}_{5}$ (banded TSP). The isolines corresponding to $90 \%$ of the maximum yield $(0.9$ $\hat{Y}_{\max }$ had a value of approximately $2880 \mathrm{~kg} \mathrm{ha}^{-1}$. The minimum P rate, applied as banded TSP, to reach this value was 100 $\mathrm{kg} \mathrm{ha}{ }^{-1}$ of $\mathrm{P}_{2} \mathrm{O}_{5}$ when associated to the residual effect of the application of $350 \mathrm{~kg} \mathrm{ha}^{-1}$ of $\mathrm{P}_{2} \mathrm{O}_{5}$ (broadcast PR) (Figure 3b).
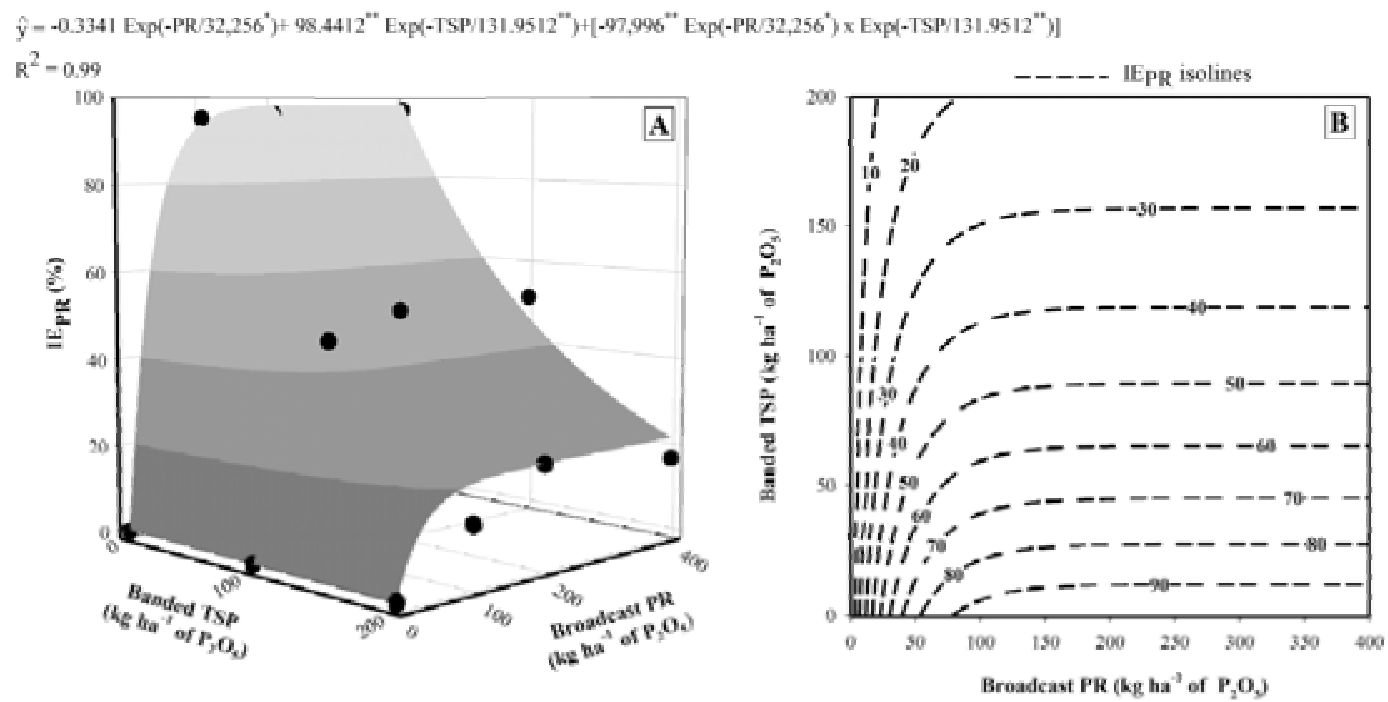

Figure 2 - Immediate effect of phosphate rock $\left(\mathrm{IE}_{\mathrm{PR}}\right)$ estimate based on soybean yield in the first crop year (2004/05), as a function of broadcast PR and banded TSP applications at the same crop year (A), and the corresponding isolines for the adjusted regression model (B).
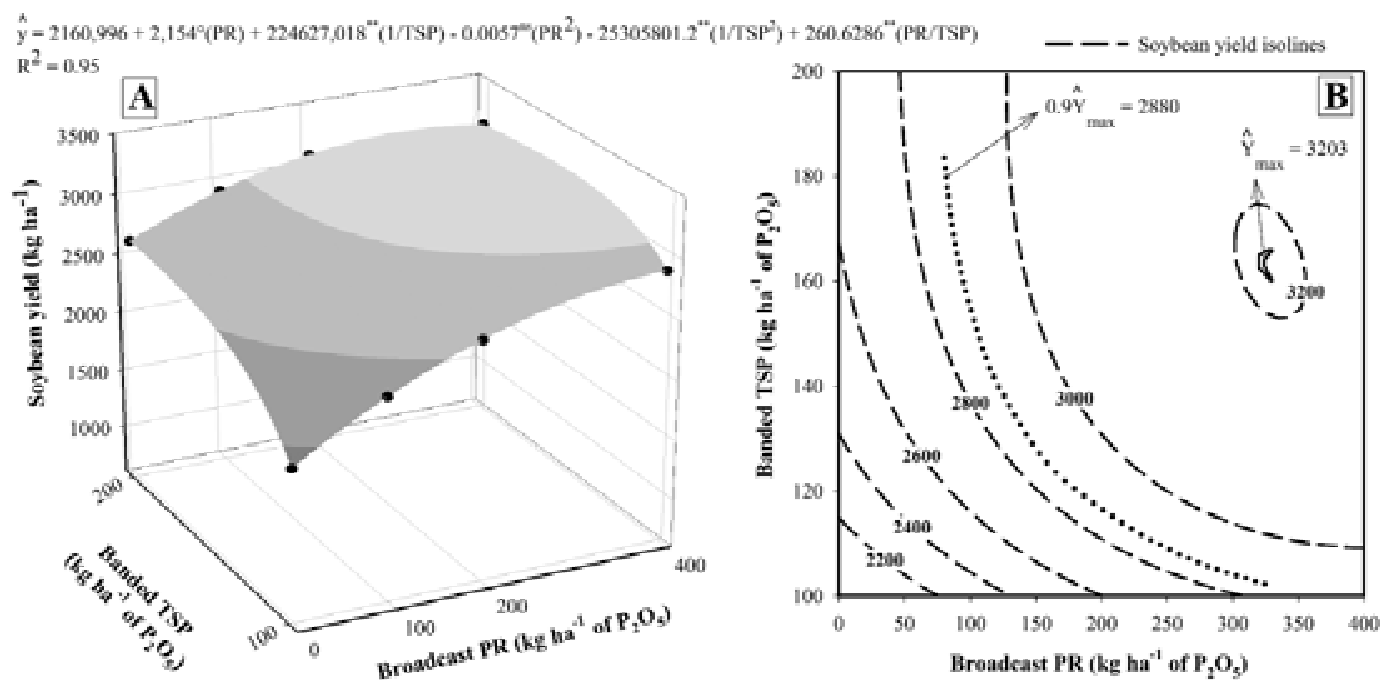

Figure 3 - Soybean yield in the $2^{\text {nd }}$ crop year $(2005 / 06)$ as a function of broadcast PR applied in the first crop year (2004/05) and banded TSP applied in the first $(2004 / 05)$ and $2^{\text {nd }}(2005 / 06)$ crop years (A), and the corresponding isolines for the adjusted regression model (B). 
PR residual effect $\left(\mathrm{RE}_{\mathrm{pR}}\right)$ in the $2^{\text {nd }}$ crop year $(2005 / 06)$ was calculated considering the annual application of 100 and $200 \mathrm{~kg} \mathrm{ha}^{-1}$ of $\mathrm{P}_{2} \mathrm{O}_{5}$ as TSP (Figure 4). This procedure was adopted because the initial experiment design did not include treatments referring to PR applied only in the first year and without TSP application $(100+0,200+0$, and $400+0)$.

A decrease in $\mathrm{RE}_{\mathrm{PR}}$ was registered for banded $\mathrm{P}$ rates (TSP). As TSP rates increased, reductions of $23 \%, 21 \%$, and $24 \%$ in $\mathrm{RE}_{\mathrm{PR}}$ were detected at the rates of 100,200 , and 400 $\mathrm{kg} \mathrm{ha}^{-1}$ of $\mathrm{P}_{2} \mathrm{O}_{5}$ (broadcast PR), respectively. In contrast with what was noticed for $\mathrm{IE}_{\mathrm{PR}}$ regarding the residual effect, no plateau was observed for P rates applied as PR (Figure 4a). Therefore, using rates above $200 \mathrm{~kg} \mathrm{ha}^{-1}$ of $\mathrm{P}_{2} \mathrm{O}_{5}$ as broadcast PR in the first crop year (2004/05) resulted higher $\mathrm{RE}_{\mathrm{PR}}$ in the following crop (Figure 4b). PR application presented an excellent residual effect, especially when associated to the lowest banded $\mathrm{P}$ rate. For example, the residual effect of broadcast PR at the rate of $400 \mathrm{~kg} \mathrm{ha}^{-1}$ of $\mathrm{P}_{2} \mathrm{O}_{5}$ associated to the annual application of banded TSP at the rate of $100 \mathrm{~kg}$ $\mathrm{ha}^{-1}$ of $\mathrm{P}_{2} \mathrm{O}_{5}$ made a contribution of $35-40 \%$ to the final yield value (2839 $\mathrm{kg} \mathrm{ha}^{-1}$ ) (Figure 3a), representing approximately $1,100 \mathrm{~kg} \mathrm{ha}{ }^{-1}$ of soybeans produced as a result of PR residual effect.

In the $3^{\text {rd }}$ crop year $(2006 / 07)$, soybean yield was evaluated as a function of the residual effect of broadcast PR applied in the first crop year $(2004 / 2005)$ and banded TSP applied in the first $(2004 / 05)$ and $2^{\text {nd }}(2005 / 06)$ crop years (Figure 5). The maximum yield $\left(3,290 \mathrm{~kg} \mathrm{ha}^{-1}\right)$ resulted from the highest $\mathrm{P}$ rates, regardless of the source used (Figure $5 \mathrm{~b}$ ). Several combinations of PR and TSP produced yields higher than $3,000 \mathrm{~kg} \mathrm{ha}^{-1}$. The extreme combinations were $0+200$ and $400+150$, meaning that the minimum annual input of soluble $\mathrm{P}$ sources to obtain yields of at least $3,000 \mathrm{~kg} \mathrm{ha}^{-1}$ in the $3^{\text {rd }}$ crop year $(2006 / 07)$ based on their residual effect was $150 \mathrm{~kg} \mathrm{ha}{ }^{-1}$ of $\mathrm{P}_{2} \mathrm{O}_{5}$, regardless the PR application.
The $\mathrm{RE}_{\mathrm{pR}}$ values for the $3^{\text {rd }}$ crop year $(2006 / 2007)$ (Table 3) ranged from $5 \%$ to $13 \%$ when banded TSP was applied at the rate of $200 \mathrm{~kg} \mathrm{ha}^{-1}$ of $\mathrm{P}_{2} \mathrm{O}_{5}$ in the first $(2004 / 05)$ and $3^{\text {rd }}$ crop years $(2006 / 07)$, and from $28 \%$ to $31 \%$ when the soluble source was used at the rate of $100 \mathrm{~kg} \mathrm{ha}^{-1}$ of $\mathrm{P}_{2} \mathrm{O}_{5}$. Even under the residual effect of TSP application, the base yields for $\mathrm{RE}_{\mathrm{PR}}$ calculation were not very low (around 1,900 $\mathrm{kg} \mathrm{ha}{ }^{-1}$ at the rate of $100 \mathrm{~kg} \mathrm{ha}^{-1}$ of $\mathrm{P}_{2} \mathrm{O}_{5}$ and approximately $2,900 \mathrm{~kg} \mathrm{ha}^{-1}$ at the rate of $200 \mathrm{~kg} \mathrm{ha}^{-1}$ of $\mathrm{P}_{2} \mathrm{O}_{5}$ ), providing evidence that the residual effect of PR applied two crop years before is expressive and consistent, especially when associated to the lowest rate of banded P.

Considering the average yields for the three crop years (Table 4), the joint application of both sources presented no statistically significant difference (Tukey at $5 \%$ ) in relation to the application of TSP alone (both broadcast and banded) at the rate of $800 \mathrm{~kg} \mathrm{ha}^{-1}$ of $\mathrm{P}_{2} \mathrm{O}_{5}$ (treatments 1, 2, and 3). The intermediate (400 and $600 \mathrm{~kg} \mathrm{ha}^{-1}$ of $\left.\mathrm{P}_{2} \mathrm{O}_{5}\right)$ and lower $(300 \mathrm{~kg}$ $\mathrm{ha}^{-1}$ of $\mathrm{P}_{2} \mathrm{O}_{5}$ ) rates of $\mathrm{P}$ presented similar or higher responses for the joint application compared to the individual applications of each source. For instance, the annual broadcast TSP application at the rate of $100 \mathrm{~kg} \mathrm{ha}^{-1}$ of $\mathrm{P}_{2} \mathrm{O}_{5}$ (treatment 14) resulted in an average yield of $2,077 \mathrm{~kg} \mathrm{ha}^{-1}$, lower than the yield $\left(2,567 \mathrm{~kg} \mathrm{ha}^{-1}\right)$ obtained in treatment 13 with the application of $100 \mathrm{~kg} \mathrm{ha}^{-1}$ of $\mathrm{P}_{2} \mathrm{O}_{5}$ (broadcast PR in the first crop year - 2004/05) in association with the annual application of $100 \mathrm{~kg} \mathrm{ha}^{-1}$ of $\mathrm{P}_{2} \mathrm{O}_{5}$ (banded TSP in the first - 2004/05 and $2^{\text {nd }}$ crop years $\left.-2005 / 06\right)$. These results indicate that the association of sources can be an agronomically feasible practice, although further studies are necessary. Similar results were obtained by Franzini et al. (2009a), who reported that the relative agronomic effectiveness of Gafsa PR associated to TSP (1:1) was as good as that obtained with the use of TSP for soybean dry matter yield under controlled conditions.

In the 1 st $(2004 / 05)$ and in the $2^{\text {nd }}(2005 / 06)$ crop years, when the "mixtures" were applied in the seed row, crop re-
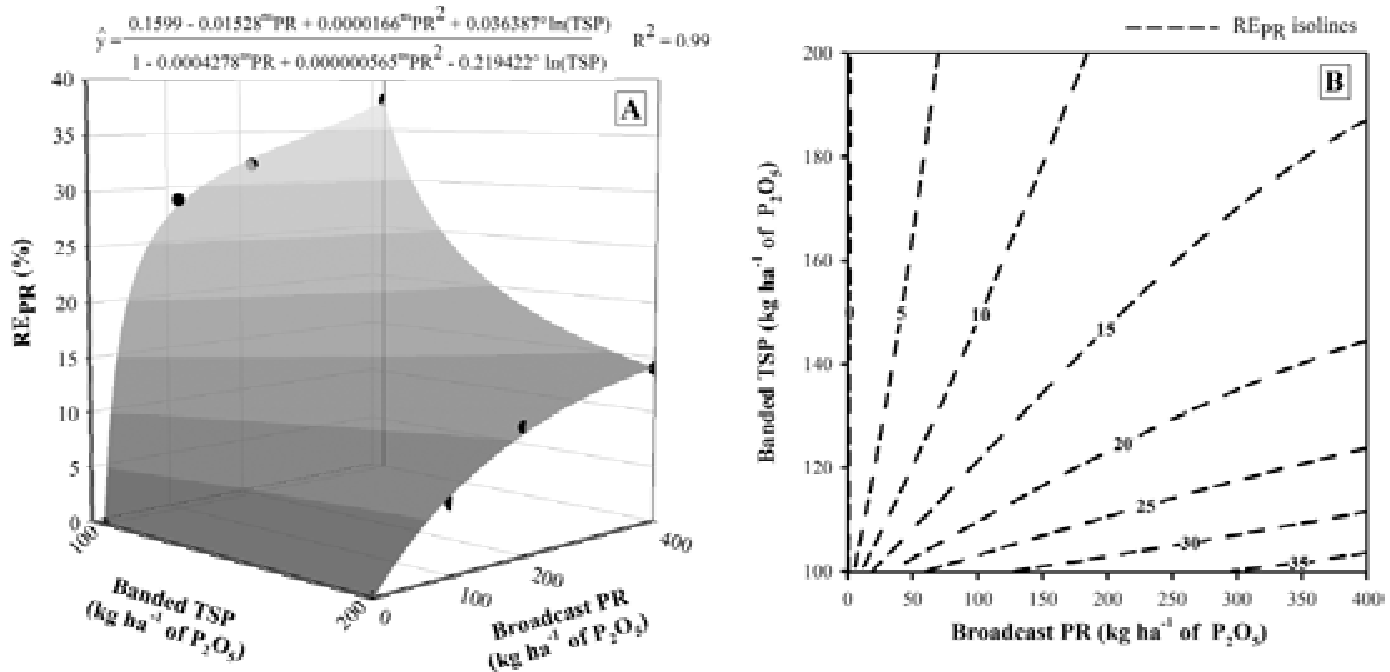

Figure 4 - Phosphate rock residual effect $\left(\mathrm{RE}_{\mathrm{PR}}\right)$ estimate based on soybean yield in the $2^{\text {nd }}$ crop year $(2005 / 06)$ as a function of broadcast PR applied in the first crop year (2004/05) and banded TSP applied in the first $(2004 / 05)$ and $2^{\text {nd }}(2005 / 06)$ crop years (A), and the corresponding isolines for the adjusted regression model (B).

Sci. Agric. (Piracicaba, Braz.), v.68, n.3, p.376-385, May/June 2011 
Table 3 - Phosphate rock residual effect $\left(\mathrm{RE}_{\mathrm{PR}}\right)$ estimate based on soybean yield in the $3^{\text {rd }}$ crop year $(2006 / 07)$ in response to broadcast PR applied in the first crop year (2004/2005) and banded TSP applied in the first (2004/05) and $2^{\text {nd }}(2005 /$ 06) crop years.

\begin{tabular}{|c|c|c|c|c|c|c|c|c|c|}
\hline \multicolumn{6}{|c|}{ P rate ${ }^{A}$} & \multirow{3}{*}{ Soybean yield $(\mathrm{Y})$} & \multirow{3}{*}{$\Delta \mathrm{Y}_{\mathrm{PR}+\mathrm{TSP}}$} & \multirow{3}{*}{$\Delta \mathrm{Y}_{\mathrm{PR}}$} & \multirow{3}{*}{$\mathrm{RE}_{\mathrm{PR}}$} \\
\hline \multicolumn{2}{|c|}{$2004 / 05$} & \multicolumn{2}{|c|}{$2005 / 06$} & \multicolumn{2}{|c|}{$2006 / 07$} & & & & \\
\hline PR & TSP & PR & TSP & PR & TSP & & & & \\
\hline--- & 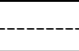 & \multicolumn{4}{|c|}{$\mathrm{kg} \mathrm{ha}{ }^{-1}$ of $\mathrm{P}_{2} \mathrm{O}_{5}$} & \multicolumn{3}{|c|}{ - } & $\%$ \\
\hline 0 & 100 & 0 & 100 & 0 & $100^{\mathrm{B}}$ & 2497 & 0 & - & - \\
\hline 0 & 200 & 0 & 200 & 0 & $200^{\mathrm{B}}$ & 3271 & 0 & - & - \\
\hline 0 & 100 & 0 & 100 & 0 & 0 & 1934 & -563 & 0 & 0 \\
\hline 0 & 200 & 0 & 200 & 0 & 0 & 2900 & -370 & 0 & 0 \\
\hline 100 & 100 & 0 & 100 & 0 & 0 & 2678 & 181 & 744 & 28 \\
\hline 100 & 200 & 0 & 200 & 0 & 0 & 3063 & -208 & 163 & 5 \\
\hline 200 & 100 & 0 & 100 & 0 & 0 & 2813 & 316 & 878 & 31 \\
\hline 200 & 200 & 0 & 200 & 0 & 0 & 3120 & -150 & 220 & 7 \\
\hline 400 & 100 & 0 & 100 & 0 & 0 & 2776 & 279 & 842 & 30 \\
\hline 400 & 200 & 0 & 200 & 0 & 0 & 3345 & 74 & 445 & 13 \\
\hline
\end{tabular}

${ }^{\mathrm{A}}$ Broadcast PR and banded TSP; ${ }^{\mathrm{B}}$ Broadcast TSP (subdivided plots).

Table 4 - Soybean yield as a function of total P rates and P sources applied during three crop years.

\begin{tabular}{|c|c|c|c|c|c|c|c|c|c|}
\hline \multirow{2}{*}{ Treat. $\mathrm{n}^{\mathrm{O}}$} & \multirow{2}{*}{ P source } & \multirow{2}{*}{$\begin{array}{l}\text { Method of } \\
\text { application }^{A}\end{array}$} & \multicolumn{5}{|c|}{$P$ rate } & \multirow{2}{*}{ Total $\mathrm{P}$ rate } & \multirow{2}{*}{ Yield $^{\mathrm{B}}$} \\
\hline & & & $2004 / 05$ & & $2005 / 06$ & & $2006 / 07$ & & \\
\hline & & & \multicolumn{6}{|c|}{ - $\mathrm{kg} \mathrm{ha}^{-1}$ of $\mathrm{P}_{2} \mathrm{O}_{5}$} & $\mathrm{~kg} \mathrm{ha}^{-1}$ \\
\hline 1 & TSP & Brd & 400 & + & 400 & + & 0 & 800 & 3291 a \\
\hline 2 & TSP & Bnd & 400 & + & 400 & + & 0 & 800 & $3276 \mathrm{a}$ \\
\hline 3 & $\mathrm{PR}+\mathrm{TSP}$ & Brd+Bnd & $400+200$ & + & $0+200$ & + & $0+0$ & 800 & $3181 \mathrm{ab}$ \\
\hline 4 & PR & Brd & 400 & + & 400 & + & 0 & 800 & $2638 \mathrm{def}$ \\
\hline 5 & PR+TSP & $\mathrm{Brd}+\mathrm{Bnd}$ & $200+200$ & + & $0+200$ & + & $0+0$ & 600 & $3126 \mathrm{abc}$ \\
\hline 6 & $\mathrm{PR}+\mathrm{TSP}$ & $\mathrm{Brd}+\mathrm{Bnd}$ & $400+100$ & + & $0+100$ & + & $0+0$ & 600 & $2807 \mathrm{cde}$ \\
\hline 7 & TSP & Bnd & 200 & + & 200 & + & 200 & 600 & 2794 de \\
\hline 8 & PR+TSP & Brd+Bnd & $100+200$ & + & $0+200$ & + & $0+0$ & 500 & 2942 bcd \\
\hline 9 & $\mathrm{PR}+\mathrm{TSP}$ & Brd + Bnd & $200+100$ & + & $0+100$ & + & $0+0$ & 400 & 2730 def \\
\hline 10 & TSP & Bnd & 200 & + & 200 & + & 0 & 400 & 2714 def \\
\hline 11 & TSP & Brd & 200 & + & 200 & + & 0 & 400 & $2412 \mathrm{f}$ \\
\hline 12 & PR & Brd & 200 & + & 200 & + & 0 & 400 & $2061 \mathrm{gh}$ \\
\hline 13 & $\mathrm{PR}+\mathrm{TSP}$ & Brd + Bnd & $100+100$ & + & $0+100$ & + & $0+0$ & 300 & 2567 ef \\
\hline 14 & TSP & Brd & 100 & + & 100 & + & 100 & 300 & $2077 \mathrm{~g}$ \\
\hline 15 & TSP & Brd & 100 & + & 100 & + & 0 & 200 & $1735 \mathrm{hi}$ \\
\hline 16 & TSP & Bnd & 100 & + & 100 & + & 0 & 200 & $1687 \mathrm{i}$ \\
\hline 17 & PR & Brd & 100 & + & 100 & + & 0 & 200 & $1450 \mathrm{i}$ \\
\hline 18 & Ctrl & - & 0 & + & 0 & + & 0 & 0 & $115 \mathrm{j}$ \\
\hline
\end{tabular}

${ }^{\mathrm{A}}$ Brd: broadcast application; Bnd: banded application; Brd + Bnd: broadcast PR + banded TSP applications; ${ }^{\mathrm{B}}$ Average of three crop years. Values followed by the same letter are not different $(p<0.05)$. Coefficient of variation $=4.28 \%$ MSD $_{\text {(Tukey } 5 \%)}=327 \mathrm{~kg} \mathrm{ha}{ }^{-1}$.

sponse to their solubility was linear (Figure 6). This direct relationship was probably a consequence of both the preferential use of the soluble fraction by plants (lower loss due to fertilizer location) and mainly the lower agronomic effi- ciency of the water-insoluble fraction (PR) when the contact between fertilizer and soil is reduced (Chien and Menon, 1995a, 1995b; Khasawneh and Doll, 1978; Rajan et al., 1996). On the other hand, when the "mixtures" were broadcasted, 
a plateau trend was observed as a function of solubility, with no increase in yield above approximately $50 \%$ RS in the first $(2004 / 05)$ and $2^{\text {nd }}(2005 / 06)$ crop years (Figure 6). In this case, the higher dissolution of the water-insoluble fraction of the "mixture" contributed to increase the yield and, consequently, to reach a plateau. Similarly, Motomiya et al. (2004) reported a linear increase in soybean yield with increasing proportions of TSP in a "mixture" with Gafsa PR applied in the furrow. When either the separate sources or the "mixtures" were broadcasted, Motomiya et al. (2004) did not observe differences between the application of the "mixtures" and the isolated application of TSP. These results support the need of soil contact for better drainage of the water-insoluble fraction dissolution products (Rajan et al., 1996), leading to higher agronomic efficiency of the "mixtures" when used under these conditions.

In the $3^{\text {rd }}$ crop year $(2006 / 07)$, under the residual effect of previous $\mathrm{P}$ source applications (Figure 6c), the relation- ship between yield and solubility was linear for banded application, despite the low coefficient of determination of the model applied (higher response variation under the residual effect). The broadcast application, though, resulted in a quadratic response, a trend caused by the yield decrease when TSP was applied separately. The use of the sources/"mixtures", regardless of the form of application, resulted in yields of approximately $2,500 \mathrm{~kg} \mathrm{ha}^{-1}$, close to the Brazilian average yield in this same crop year $\left(2,823 \mathrm{~kg} \mathrm{ha}^{-1}\right)$ (CONAB, 2007). This indicates that the application of these sources/ "mixtures" can result, in the long term, in economically acceptable yields, especially because no $\mathrm{P}$ was applied in the last crop year.

Although the response to solubility was linear when the sources/"mixtures" were banded, the slope of the adjusted functions for the three crop years (Figure 6) decreased from 22.44 in the first $(2004 / 05)$, to 15.92 in the $2^{\text {nd }}(2005 / 06)$, and finally to 7.02 in the $3^{\text {rd }}(2006 / 07)$ crop years. This indi-
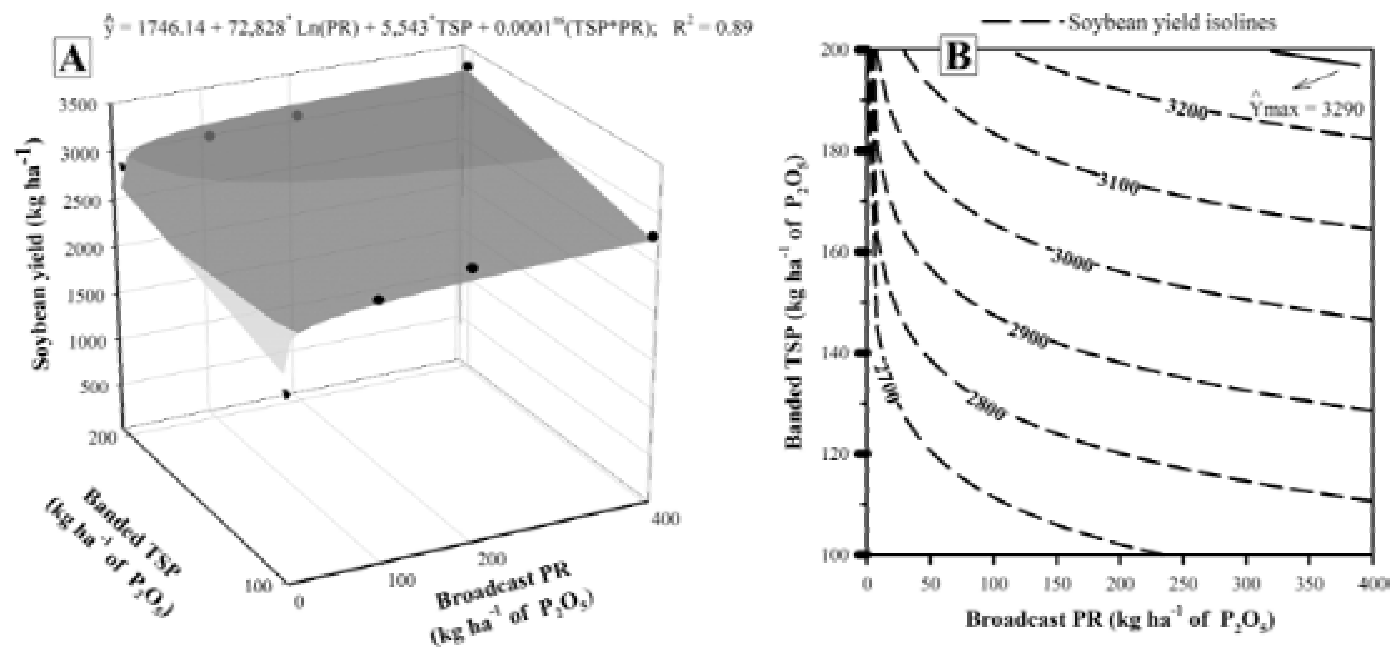

Figure 5 - Soybean yield in the $3^{\text {rd }}$ crop year (2006/07) as a function of broadcast PR applied in the first crop year (2004/05) and banded TSP applied in the first $(2004 / 05)$ and $2^{\text {nd }}(2005 / 06)$ crop years $(A)$, and the corresponding isolines for the adjusted regression model (B).

Table 5 - Orthogonal contrasts of soybean yield, during three crop years, comparing P source groups presenting low relative solubility (LRS) and high relative solubility (HRS) and comparing broadcast and banded application forms.

\begin{tabular}{|c|c|c|c|c|c|c|c|c|c|}
\hline \multirow{3}{*}{ Contrast } & \multicolumn{9}{|c|}{ Soybean yield } \\
\hline & \multicolumn{3}{|c|}{$2004 / 05$} & \multicolumn{3}{|c|}{$2005 / 06$} & \multicolumn{3}{|c|}{$2006 / 07$} \\
\hline & ${\overline{X_{1}}}^{\mathrm{A}}$ & ${\overline{X_{2}}}^{\mathrm{B}}$ & $F^{\mathrm{C}}$ & $\overline{\overline{X_{1}}}$ & $\overline{\overline{X_{2}}}$ & $F$ & $\overline{\overline{X_{1}}}$ & $\overline{X_{2}}$ & $F$ \\
\hline \multicolumn{10}{|c|}{---o- } \\
\hline (LRS) vs (HRS) for Broadcasted & 2069 & 2283 & $3.8^{*}$ & 2353 & 2662 & $34.9 * *$ & 2544 & 2587 & $3.9^{\mathrm{ns}}$ \\
\hline (LRS) vs (HRS) for Banded & 1047 & 2266 & $123.6^{* *}$ & 1673 & 2500 & $250.2 * *$ & 2349 & 2799 & $15.2^{* *}$ \\
\hline (Broadcasted) vs (Banded) & 1534 & 2154 & $66.6 * *$ & 2004 & 2477 & $170.4^{* *}$ & 2529 & 2561 & $1.8^{\mathrm{ns}}$ \\
\hline Coefficient of variation $(\%)$ & \multicolumn{3}{|c|}{10.53} & \multicolumn{3}{|c|}{4.51} & \multicolumn{3}{|c|}{8.76} \\
\hline
\end{tabular}

$\overline{\mathrm{A}} \bar{X}_{1}$ : average soybean yield obtained with the application of $\mathrm{P}$ source groups presenting low relative solubility $\left(200+0\right.$ and $150+50 \mathrm{~kg}$ ha ${ }^{-1}$ of $\mathrm{P}_{2} \mathrm{O}_{5}-\mathrm{PR}+$ TSP) or average soybean yield obtained with broadcast application of P sources/“mixtures"; ${ }^{\mathrm{B}} \overline{\mathrm{X}_{2}}$ : average soybean yield obtained with the application of $\mathrm{P}$ source groups presenting high relative solubility $\left(100+100 ; 50+150\right.$, and $0+200 \mathrm{~kg} \mathrm{ha}^{-1}$ of $\mathrm{P}_{2} \mathrm{O}_{5}-\mathrm{PR}$ + TSP) or average of soybean yield obtained with banded application of P sources/ "mixtures"; Cns, **, * non-significant, and significant at $1 \%$ and $5 \%$, respectively. 


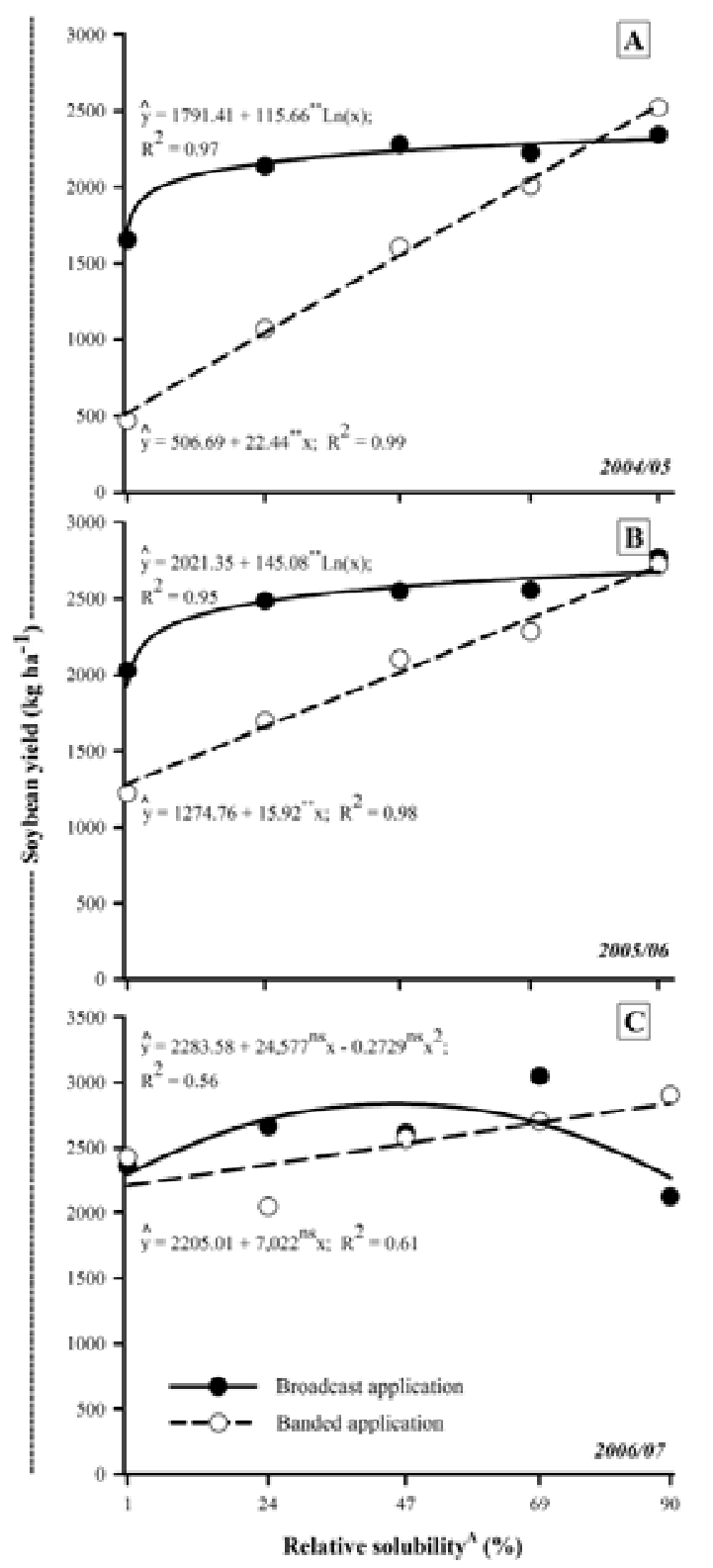

${ }^{A}$ Extreme values of solubility (1\% and 90\%) correspond to the respective uses of PR and TSP alone; $P$ rate: $200 \mathrm{~kg} \mathrm{ha}{ }^{-1}$ of $\mathrm{P}_{2} \mathrm{O}_{5}$.

Figure 6 - Relationship between soybean yield, in the first (2004/ 05) (A), $2^{\text {nd }}(2005 / 06)(B)$ and $3^{\text {rd }}(2006 / 07)$ crop years $(\mathrm{C})$, and the relative solubility of $\mathrm{P}$ sources/ "mixtures".

cates that, as time passes by, the water-insoluble fraction of the "mixtures" and PR contributes more effectively to the final yield results (increase in the intercept values of the equations) due to much more representative soil-fertilizer contact. Sousa and Lobato (2003) emphasized the importance of the contact between soil and PR to increase the relative agronomic effectiveness of this source of $\mathrm{P}$, as time goes by, in banded applications.

Regarding the average of the three crop years (Figure 7), the crop clearly presented a linear response to solubility when

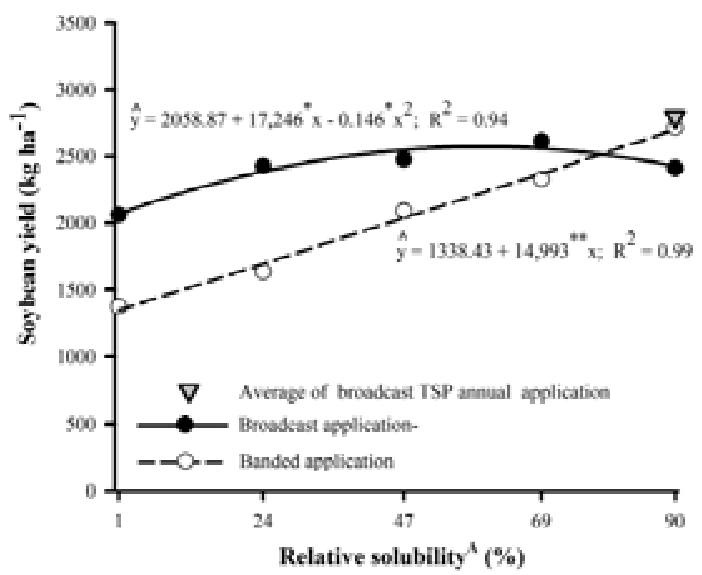

${ }^{A}$ Extreme values of solubility (1\% and 90\%) correspond to the respective uses of PR and TSP alone; $P$ rate: $200 \mathrm{~kg} \mathrm{ha}{ }^{-1}$ of $\mathrm{P}_{2} \mathrm{O}_{5}$.

Figure 7 - Average soybean yield, during three crop years, in response to the relative solubility of $\mathrm{P}$ sources/ "mixtures".

the sources/"mixtures" were banded and a quadratic response when they were broadcasted, with the maximum point of the equation at $60 \%$ of RS.

When the sources/"mixtures" with higher RS (TSP:PR - 200:0 and 150:50) were compared to those with lower RS (100:100, 150:50, and 0:200) by orthogonal contrasts (Table $5)$, it was evident that, within the period of $\mathrm{P}$ application, the responses of sources/"mixtures" with higher RS were higher $(p \leq 0.05)$ than those shown by those with lower RS, regardless of the form of application. Nevertheless, under the residual effect, this difference was observed only for the banded application, corroborating once more the importance of soil contact as well as time (number of crops) for higher water-insoluble fraction dissolution.

Comparing application forms based on the average value of sources/"mixtures" (Table 5), we observed differences between the first two crops, broadcast application resulting higher yields (Figure $6 \mathrm{a}$ and $6 \mathrm{~b})$. However, in the $3^{\text {rd }}$ crop year $(2006 / 07)$, this difference was not observed, since the banded application of the "mixtures" with lower RS resulted in better responses compared to the two previous crops (Figure 6c).

The fact that no RS "critical level" was obtained when the sources were banded is likely to be related to the application of TSP in a granular form, which would result in a higher crop recovery efficiency of $\mathrm{P}$ applied, and, additionally, PR presented lower efficiency when banded. Consequently, both factors would contribute to a linear response as a function of RS.

\section{Conclusions}

The joint application of $\mathrm{P}$ sources seems to be an agronomically feasible option, since the residual effect of PR remains in the soil for at least two crop years. It is possible to determine $\mathrm{P}$ rates not only as a function of yield, but also as a function of aspects related to the cost of each source and to $\mathrm{PR}$ residual effect, enabling better $\mathrm{P}$ fertilizer application 
planning for soybean crop. Applying P sources as "mixtures" also seems to be agronomically feasible. In case of broadcast application, the point at which water solubility does not directly influence soybean yield was estimated in $60 \%$ considering the average of three crops.

\section{References}

Chien, S.H.; Adams, F.; Khasawneh, F.E.; Henao, J. 1987. Effects of combinations of triple superphosphate and a reactive phosphate rock on yield and phosphorus uptake by corn. Soil Science of American Journal 51: 1656-1658.

Chien, S.H.; Menon, R.G. 1995a. Agronomic evaluation of modified phosphate rock products. IFDC's experience. Fertilizer Research 41: 197-209.

Chien, S.H.; Menon, R.G. 1995b. Factors affecting the agronomic effectiveness of phosphate rock for direct application. Fertilizer Research 41: 227-234.

Chien, S.H.; Prochnow, L.I.; Cantarella, H. 2009. Recent developments of fertilizer production and use to improve nutrient efficiency and minimize environmental impacts. Advances in Agronomy 102: $267-322$.

Companhia Nacional de Abastecimento [CONAB]. 2007. Brazilian crop production follow-up; Grains 2006/2007 season; twelfth survey, September 2007. Available at: http://www.conab.gov.br/ conabweb/download/safra/12_levantamento_set2007.pdf. [Accessed Oct. 23, 2007]. (in Portuguese).

Empresa Brasileira de Pesquisa Agropecuária [Embrapa]. 2003. Soybean production technology: Central Region of Brazil, 2004. Embrapa Soja/EPAMIG: Fundação Triângulo, Londrina, PR, Brazil. (Sistemas de Produção, 4). (in Portuguese).

Franzini, V.I.; Muraoka, T.; Coraspe-León, H.M.; Mendes, F.L. 2009a. Efficiency of reactive phosphate rock applied in mixtures with triple superphosphate in maize and soybean. Pesquisa Agropecuária Brasileira 44: 1092-1099. (in Portuguese, with abstract in English).

Franzini, V.I.; Muraoka, T.; Mendes, F.L. 2009b. Ratio and rate effects of ${ }^{32} \mathrm{P}$-triple superphosphate and phosphate rock mixtures on corn growth. Scientia Agricola 66: 71-76.

Khasawneh; F.E.; Doll, E.C. 1978. The use of phosphate rock for direct application to soils. Advances in Agronomy 30: 159-207.

Leal, J.R.; Velloso, A.C.X. 1973. Phosphorus adsorption in Oxisols from Brazilian Savannas. Pesquisa Agropecuária Brasileira 8: 81-88. (in Portuguese, with abstract in English).

Lopes, A.S.; Cox, F.R. 1977. A survey of the fertility status of surface soils under "Cerrado" vegetation in Brazil. Soil Science Society of American Journal 41: 742-747.
Menon, R.G.; Chien, S.H.; Gadalla, A N. 1991. Phosphate rock compacted with superphosphates vs. partially acidulated rocks for bean and rice. Soil Science Society of America Journal 55: 1480-1484.

Motomiya, W.R; Fabrício, A.C.; Marchetti, M.E.; Gonçalves, M.C.; Robaina, A.D.; Novelino, J.O. 2004. Phosphate application methods for soybean under no-tillage system. Pesquisa Agropecuária Brasileira 39: 307-312. (in Portuguese, with abstract in English).

Nachtigall, G.R.; Brauner, J.L.; Zolezzi, M.; Tapia, F. 1989. Blend of triple superphosphate with phosphate of Jacupiranga in the same granule about the efficiency of the natural phosphate. Revista Brasileira de Ciência do Solo 13: 269-273. (in Portuguese, with abstract in English).

Pimentel-Gomes, F.; Conagin, A. 1991. Fertilization experiments: planning and statistics analysis. p. 103-188. In: Oliveira, A.J.; Garrido, W.E; Araujo, J.D.; Lourenço, S., eds. Methods to research soil fertility. Embrapa, Brasília, DF, Brazil. (in Portuguese).

Prochnow, L.I.; Alcarde, J.C.; Chien, S.H. 2004a. Agronomic efficiency of totally acidulated phosphates. p. 605-663. In: Yamada, T.; Abdalla, S.R.S., eds. Phosphorus in Brazilian agriculture. Associação Brasileira para Pesquisa da Potassa e do Fosfato, Piracicaba, SP, Brazil. (in Portuguese).

Prochnow, L.I.; Chien, S.H.; Carmona, G.; Henao, J. 2004b. Greenhouse evaluation of phosphorus sources produced from a low-reactive Brazilian phosphate rock. Agronomy Journal 96: 761-768.

Rajan, S.S.S.; Watkinson, H.; Sinclair, A.G. 1996. Phosphate rocks for direct application to soils. Advances in Agronomy 57: 77-159.

Sousa, D.M.G.; Lobato, E. 2003. Phosphorus fertilization in the Brazilian Cerrado Region. Informações Agronômicas 102: 1-16. (in Portuguese).

Systat Software. 2006. Sigmaplot for Windows: version 10. Available at: http://www.systat.com/products/sigmaplot/. [Accessed Oct. $22,2007]$.

Systat Software. 2002. TableCurve 3D: version 4. Available at: http:// www.systat.com/products/TableCurve3D/. [Accessed Oct. 22, 2007].

Tollefson, J. 2010. The global farm. Nature 466: 554-556. Available at: http://www.nature.com/news/2010/100728/pdf/466554a.pdf. [Accessed Aug. 4, 2010].

Villanueva, F.C.A.; Muraoka, T.; Trevizam, A.R.; Franzini, V.I.; Rocha, A.P. 2006. Improving phosphorus availability from Patos phosphate rock for Eucalyptus: a study with ${ }^{32} \mathrm{P}$ radiotracer. Scientia Agricola 63: 65-69.

Received October 23, 2009

Accepted November 26, 2010 